\title{
Field Simulation of Global Change: Transplanting Northern Bog Mesocosms Southward
}

\author{
Angela Breeuwer ${ }^{1,3 *}$ Monique M. P. D. Heijmans, ${ }^{1}$ Bjorn J. M. Robroek, ${ }^{1,2}$ \\ and Frank Berendse ${ }^{1}$
} ${ }^{1}$ Nature Conservation and Plant Ecology, Wageningen University, P.O. Box 47, 6700 AA Wageningen, The Netherlands; ${ }^{2}$ Ecology and
Biodiversity, Utrecht University, Padualaan 8, 3584 CH Utrecht, The Netherlands; ${ }^{3}$ Lange Weide 41, 5397 AG Lith, The Netherlands

\begin{abstract}
A large proportion of northern peatlands consists of Sphagnum-dominated ombrotrophic bogs. In these bogs, peat mosses (Sphagnum) and vascular plants occur in an apparent stable equilibrium, thereby sustaining the carbon sink function of the bog ecosystem. How global warming and increased nitrogen $(\mathrm{N})$ deposition will affect the species composition in bog vegetation is still unclear. We performed a transplantation experiment in which mesocosms with intact vegetation were transplanted southward from north Sweden to northeast Germany along a transect of four bog sites, in which both temperature and $\mathrm{N}$ deposition increased. In addition, we monitored undisturbed vegetation in control plots at the four sites of the latitudinal gradient. Four growing seasons after transplantation, ericaceous dwarf shrubs had become much more abundant when transplanted to the warmest site which also had highest $\mathrm{N}$ deposition. As a result ericoid aboveground biomass in the transplanted mesocosms increased most
\end{abstract}

Received 18 October 2009; accepted 13 May 2010;

published online 25 June 2010

Author Contributions: Angela Breeuwer designed the study, performed research, analyzed data, and wrote the article. Monique M. P. D. Heijmans designed the study, performed research, analyzed data and wrote the article. Bjorn J. M. Robroek performed research and contributed in the writing stage. Frank Berendse designed the study and contributed new methods.

*Corresponding author; e-mail: a.breeuwer@gmail.com at the southernmost site, this site also had highest ericoid biomass in the undisturbed vegetation. The two dominant Sphagnum species showed opposing responses when transplanted southward; Sphagnum balticum height increment decreased, whereas S. fuscum height increment increased when transplanted southward. Sphagnum production did not differ significantly among the transplanted mesocosms, but was lowest in the southernmost control plots. The dwarf shrub expansion and increased $\mathrm{N}$ concentrations in plant tissues we observed, point in the direction of a positive feedback toward vascular plant-dominance suppressing peat-forming Sphagnum in the long term. However, our data also indicate that precipitation and phosphorus availability influence the competitive balance between Sphagnum, dwarf shrubs and graminoids.

Key words: temperature; nitrogen deposition; Sphagnum; Sweden; aboveground production; nutrient concentrations.

\section{INTRODUCTION}

Global change is expected to have a strong impact on temperature, precipitation, and nutrient deposition, especially at northern latitudes where the majority of peat bogs occur (Kivinen and Pakarinen 1980; Gunnarsson 2005). Predictions about future precipitation patterns show great variability, but all climate models predict an increase in temperature 
and nitrogen $(\mathrm{N})$ availability (Bouwman and others 2002; Solomon and others 2007).

Ombrotrophic bog vegetation is often dominated by peat mosses (Sphagnum spp.), which are responsible for the long-lasting accumulation of carbon in bogs, due to their low litter decomposition rates (Coulson and Butterfield 1978; Clymo and Hayward 1982; Limpens and Berendse 2003). The vascular plant cover in bogs is generally low and consists of ericoids, graminoids, and a few forbs (some of them carnivorous), that are adapted to the nutrient poor, wet, acidic, and partly anoxic conditions (Rydin and Jeglum 2006). The sparse vascular plant cover largely results from the ability of Sphagnum to create a harsh environment, that is, low pH, low nutrient availability, which favors Sphagnum growth (Rydin and Jeglum 2006; Van Breemen 1995). To avoid being overgrown, vascular plants have to keep up with the vertical height increment of Sphagnum (Backeus 1985; Malmer and others 1994; Dorrepaal and others 2006). On the other hand, the presence of vascular plants provides a matrix for the Sphagnum to grow on (Malmer and others 1994) and reduces evaporation from Sphagnum (Heijmans and others 2001a). However, when vascular plant cover becomes too high, the increased shading can adversely affect Sphagnum growth (Berendse and others 2001; Bubier and others 2007).

In bog ecosystems, the vascular plants and Sphagnum occur in an apparent stable equilibrium, thereby sustaining the functioning of the bog ecosystem and its high carbon sequestration. Changes that affect the stability of this equilibrium can have marked effects on the carbon dynamics and $\mathrm{CO}_{2}$ fluxes of the ecosystem (Ward and others 2009). As Sphagnum and vascular plant production are both controlled by temperature, light, moisture, and nutrient availability, but have a highly asymmetrical competition (Rydin and Jeglum 2006); changes in temperature and $\mathrm{N}$ availability are likely to influence the current competitive balance.

In general, climate warming is expected to increase Sphagnum productivity, as long as water does not become limiting (Gunnarsson 2005; Dorrepaal and others 2006; Breeuwer and others 2008a). This is important as increased temperature increases evaporation, and thus indirectly decreases the availability of water (Bragazza 2008; Breeuwer and others 2008a). Increased $\mathrm{N}$ deposition has been shown to enhance Sphagnum production at locations where $\mathrm{N}$ is a limiting nutrient (Turunen and others 2004), but when $\mathrm{N}$ concentrations exceed a critical threshold value, Sphagnum production and cover are reduced (Gunnarsson and Rydin 2000;
Berendse and others 2001; Bragazza and others 2006; Gerdol and others 2007). Vascular plant cover and production are stimulated by increased temperature and $\mathrm{N}$ deposition (Berendse and others 2001; Bubier and others 2007; Wiedermann and others 2007). Apart from a direct effect, increased temperature can indirectly increase nutrient availability by enhancing decomposition and N-mineralization (Hobbie 1996; Rustad and others 2001). As Sphagnum litter decomposes much more slowly than vascular plant litter (Coulson and Butterfield 1978; Hobbie 1996; Dorrepaal and others 2005; Bragazza and others 2007), any shift in species composition will have a profound impact on the carbon sequestration function of bog ecosystems.

Although several studies have addressed the response of Sphagnum and/or vascular plants to increased temperature and/or $\mathrm{N}$ deposition, little research has been done on the combined effects of these aspects of global change on intact bog vegetation (but see Wiedermann and others 2007). In this study, we investigated the responses of both vascular plants and Sphagnum to expected effects of global change along a transect in which both temperature and $\mathrm{N}$ deposition increase. Therefore, we transplanted intact mesocosms southward between four bogs spanning a range from north Sweden to north-east Germany. During four growing seasons, we monitored Sphagnum growth and vegetation composition in the transplanted mesocosms and in additional control plots at the four sites of the latitudinal gradient. We expected that southward there would be (1) increased vascular plant cover due to increased nutrient availability and (2) reduced Sphagnum growth due to high $\mathrm{N}$ deposition and increased shading by vascular plants.

\section{Materials ANd Methods}

\section{Study Sites}

The experiment was executed between May 2003 and August 2006 (that is, spanning four growing seasons) in four Sphagnum-dominated bogs, situated along a latitudinal gradient from the north of Sweden to the north of Germany (Figure 1). We selected bog sites that were relatively undisturbed, with a peat layer of at least $5 \mathrm{~m}$ deep and a vegetation characteristic of ombrotrophic mires.

(1) The northernmost site is Lappmyran (N-Sw), approximately $50 \mathrm{~km}$ north-west of Umeå, Sweden $\left(64^{\circ} 10^{\prime} \mathrm{N}, 19^{\circ} 35^{\prime} \mathrm{E}\right)$, altitude $300 \mathrm{~m}$ a.s.l. This bog is elongated, being about $700 \mathrm{~m}$ long and $200 \mathrm{~m}$ wide, and is surrounded by forest of Pinus sylvestris 


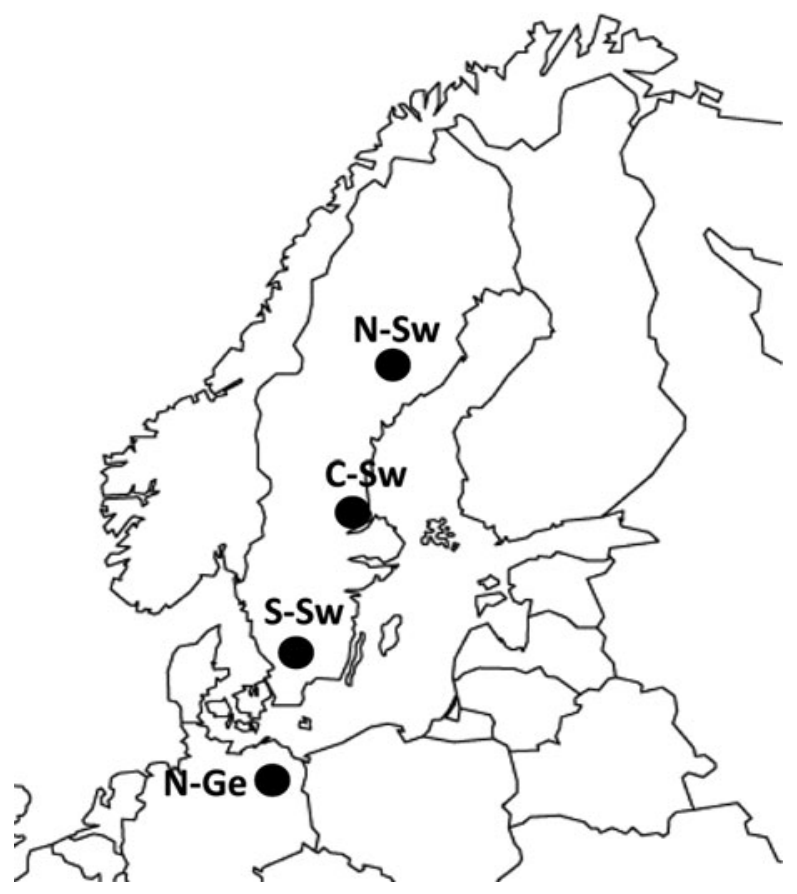

Figure 1. Location of research sites.

and Picea abies. It exhibits a pattern of strings of hollows and hummocks. The hollows are dominated by Sphagnum balticum (Russow) Russow ex C. Jens. and Scheuchzeria palustris L., whereas the hummock vegetation consists of Sphagnum fuscum (Schimp) Klinggr with a vascular plant cover consisting of Andromeda polifolia L., Calluna vulgaris (L.) Hull, Drosera rotundifolia L., Empetrum nigrum L., Eriophorum vaginatum L., Vaccinium oxycoccus L., and Rubus chamaemorus L.

(2) The central Swedish site is Åkerlänna Römosse (C-Sw), approximately $30 \mathrm{~km}$ north-west of Uppsala, Sweden $\left(60^{\circ} 01 \mathrm{~N}, 17^{\circ} 22 \mathrm{E}\right)$, altitude $50 \mathrm{~m}$ a.s.l. This bog is more oval: about $1300 \mathrm{~m}$ long and $600 \mathrm{~m}$ wide and a belt of $P$. sylvestris and P. abies separates it from the surrounding farmland. The peatland surface has a characteristic microtopography of hollows, lawns, and hummocks. The dominant species are: Sphagnum lindbergii Schimp. in deeper hollows, S. balticum in hollows, and lawns and $S$. fuscum on hummocks, with vascular plant cover of A. polifolia, C. vulgaris, D. rotundifolia, E. nigrum, E. vaginatum, and $V$. oxycoccus.

(3) The south Swedish site is Saxnäs mosse (S-Sw), approximately $40 \mathrm{~km}$ north-east of Halmstad, Sweden $\left(56^{\circ} 51^{\prime} \mathrm{N}, 13^{\circ} 28^{\prime} \mathrm{E}\right)$, altitude $160 \mathrm{~m}$ a.s.l. This bog is elongated, around $1000 \mathrm{~m}$ long and $300 \mathrm{~m}$ wide, lies next to a main road and is surrounded by forest consisting mainly of $P$. sylvestris and $P$. abies. Saxnäs mosse has typical raised bog vegetation with a mosaic of hollows, lawns and small hummocks. The dominant species are: Sphagnum cuspidatum Ehrh. Ex Hoffm. in the hollows, Sphagnum magellanicum Brid. in lawns and $S$. fuscum on hummocks, with vascular plant cover of Rhynchospora alba (L.) Vahl in hollows and A. polifolia, C. vulgaris, D. rotundifolia, Erica tetralix L., E. vaginatum and $V$. oxycoccus on lawns, and hummocks.

(4) The southernmost site is Barschpfuhl (N-Ge), approximately $65 \mathrm{~km}$ north-east of Berlin, Germany $\left(53^{\circ} 03^{\prime} \mathrm{N}, 13^{\circ} 5 \mathrm{l}^{\prime} \mathrm{E}\right)$, altitude $80 \mathrm{~m}$ a.s.l. The mire is situated in a restricted-access part of the UNESCO nature reserve Biosphärenreservat Schorfheide-Chorin. Barschpfuhl is a small mire, about $180 \mathrm{~m}$ long and $140 \mathrm{~m}$ wide, and is located in a depression. There is no clear distinction between hollows and hummocks and the vegetation is dominated by S. magellanicum and S. fallax (Klinggr.) Klinggr. with a vascular plant cover of mainly C. vulgaris, Carex rostrata, D. rotundifolia, Eriophorum angustifolium (Honckeny), E. vaginatum, R. alba, and V. oxycoccus.

Differences between the sites in temperature, precipitation, effective precipitation, water level, and atmospheric $\mathrm{N}$ deposition are described in Table 1.

\section{Experimental Set-Up}

In the second week of May 2003, we collected peat mesocosms (diameter: $45 \mathrm{~cm}$, depth: $40 \mathrm{~cm}$ ) with intact vegetation from the two northern sites, that is, N-Sw and C-Sw. The mesocosms were dug out as one piece and immediately placed in similar sized containers, which were perforated at the bottom to allow exchange of water. The containers were then either replaced in their site of origin, or transplanted southward with five replicates. The transplantation of all mesocosms was completed within 7 days under cool and wet weather conditions. We did not transplant mesocosms from south to north because this would not have yielded information on how the vegetation of ombrotrophic bogs responds to the two anticipated environmental changes (that is, increased temperature and $\mathrm{N}$ deposition) under investigation. As a result the mesocosms originating from $\mathrm{N}-\mathrm{Sw}$ have been transplanted to four sites (N-Sw, C-Sw, S-Sw, $\mathrm{N}-\mathrm{Ge}$ ) and the mesocosms from C-Sw to three sites (C-Sw, S-Sw, N-Ge). We did also perform transplants from S-Sw to N-Ge, but unsuccessfully. It was clear that the mesocosms from S-Sw were severely disturbed by the transplantation treatment. Particularly S. cuspidatum suffered from the 
Table 1. Seasonal Temperature, Precipitation, and Effective Precipitation (Precipitation Minus Potential Evapotranspiration) in the Four Study Sites during the Experimental Period

\begin{tabular}{|c|c|c|c|c|c|c|c|c|c|c|c|c|c|}
\hline \multirow[t]{2}{*}{ Season } & \multirow[t]{2}{*}{ Year } & \multicolumn{4}{|c|}{ Temperature $\left({ }^{\circ} \mathrm{C}\right)$} & \multicolumn{4}{|c|}{ Sum precipitation $(\mathrm{mm})$} & \multicolumn{4}{|c|}{ Effective precipitation $(\mathrm{mm})$} \\
\hline & & $\mathrm{N}-\mathrm{SW}$ & $\mathrm{C}-\mathrm{Sw}$ & S-Sw & $\mathrm{N}-\mathrm{Ge}$ & $\mathrm{N}-\mathrm{Sw}$ & C-Sw & S-Sw & $\mathrm{N}-\mathrm{Ge}$ & $\mathrm{N}-\mathrm{Sw}$ & C-Sw & $S-S w$ & $\mathrm{~N}-\mathrm{G}$ \\
\hline \multirow[t]{4}{*}{ Spring } & 2003 & 2.9 & 5.7 & 6.1 & 8.8 & 79 & 117 & 199 & 59 & -61 & -53 & 34 & -15 \\
\hline & 2004 & 2.6 & 5.5 & 6.6 & 8.8 & 93 & 92 & 182 & 69 & -48 & -82 & 2 & -11 \\
\hline & 2005 & 1.2 & 3.7 & 5.0 & 8.1 & 86 & 79 & 130 & 121 & -65 & -89 & -50 & $-\varepsilon$ \\
\hline & 2006 & 0.6 & 3.1 & 3.8 & 7.4 & 120 & 120 & 223 & 131 & -10 & -35 & 74 & -55 \\
\hline \multirow[t]{4}{*}{ Summer } & 2003 & 14.6 & 16.8 & 16.4 & 19.1 & 275 & 153 & 283 & 152 & 5 & -137 & 2 & -183 \\
\hline & 2004 & 13.1 & 15.4 & 14.8 & 17.1 & 239 & 184 & 408 & 245 & -9 & -92 & 164 & -2 \\
\hline & 2005 & 13.9 & 15.7 & 15.1 & 16.9 & 276 & 272 & 328 & 180 & 22 & -6 & 64 & -1 \\
\hline & 2006 & 15.4 & 17.7 & 16.7 & 19.3 & 95 & 155 & 223 & 121 & -229 & -179 & -80 & -222 \\
\hline \multirow[t]{3}{*}{ Autumn } & 2003 & 2.3 & 6.1 & 6.9 & 8.6 & 113 & 129 & 166 & 132 & 57 & 59 & 84 & \\
\hline & 2004 & 2.2 & 6.0 & 6.8 & 9.4 & 158 & 150 & 296 & 91 & 110 & 82 & 222 & -12 \\
\hline & 2005 & 4.4 & 7.8 & 7.8 & 10.1 & 94 & 87 & 173 & 108 & 37 & 7 & 87 & - \\
\hline \multirow[t]{3}{*}{ Winter } & 2003 & -6.8 & -2.5 & -1.0 & 0.7 & 115 & 147 & 224 & 129 & 106 & 132 & 203 & \\
\hline & 2004 & -5.0 & -0.7 & 0.4 & 1.4 & 135 & 120 & 265 & 94 & 127 & 105 & 246 & \\
\hline & 2005 & -6.6 & -3.2 & -2.4 & -1.5 & 90 & 88 & 115 & 88 & 81 & 74 & 97 & \\
\hline Average $p$ & year & 3.9 & 7.0 & 7.4 & 9.6 & 550 & 533 & 907 & 483 & 121 & 0 & 385 & -157 \\
\hline
\end{tabular}

Potential evapotranspiration was calculated based on solar radiation and temperature data using the Makkink equation. For location of study sites, see Figure 1. Data from Sveriges Meteorologiska och Hydrologiska Institut (SMHI) from weather stations Vindeln, $21 \mathrm{~km}$ from N-Sw; Uppsala, $27 \mathrm{~km}$ from C-Sw; Ljungby and Torup, 30 and $26 \mathrm{~km}$ from S-Sw; Deutscher Wetterdienst (DWD) data from Angermunde, $11 \mathrm{~km}$ from N-Ge. Spring = Mar-May, summer $=$ Jun-Aug, autumn $=$ Sep-Nov, winter $=$ Dec-Feb.

disturbance of digging out the mesocosms resulting in zero height growth during four growing seasons following transplantation (data not shown). Therefore, in this paper we only show data from the mesocosms originating from the two northern sites, N-Sw and C-Sw, which have been transplanted to four and three sites, respectively.

All mesocosms were taken from and placed at the hollow-hummock or hollow-lawn transition, so that the Sphagnum layer consisted of a 1:1 mix of the two dominant Sphagnum species in each site. Because the sites differed in their species composition, the dominant Sphagnum species also differed between sites. In N-Sw and C-Sw the mesocosms consisted mainly of $S$. balticum and S. fuscum, in S-Sw the mesocosms consisted mainly of S. cuspidatum and S. magellanicum, and in N-Ge, where no distinctive microtopography was apparent, the vegetation consisted of S. fallax and S. magellanicum. Although Sphagnum species composition in the two southernmost sites was different from the two northernmost sites, all mesocosms were taken from and placed in plots at intermediate microtopographical position. All mesocosm positions had in common that they contained 90-100\% Sphagnum cover and relatively sparse vascular plant cover consisting of a mixture of graminoids and ericaceous dwarf shrubs. The graminoid species Eriophorum vaginatum and the dwarf shrub species Vaccinium oxycoccus were present in mesocosms/plots at all four sites. Water table positions in the mesocosms were very similar in three of the four sites, with lower water tables at the southernmost site (Table 2) which we attributed to lower effective precipitation (Table 1).

In August 2003, we delineated five control plots, that is, without container, in each study site to test for the possible disturbance of cutting the mesocosms and putting them in containers. Moreover, these control plots allow for observations in undisturbed vegetation across a latitudinal gradient of increasing temperature and $\mathrm{N}$ deposition. This space-for-time substitution forms an independent way of understanding long-term ecosystem responses (Wiedermann and others 2009). These control plots had a similar species composition and were located at a similar position in microtopography as the containers.

\section{Measurements}

To compare the atmospheric deposition of $\mathrm{N}$ and $\mathrm{P}$ in the four sites, we measured accumulation of $\mathrm{NH}_{4}{ }^{+}, \mathrm{NO}_{3}{ }^{-}$, and $\mathrm{PO}_{4}{ }^{-}$on ion-exchange resins (Hobbie and Chapin 1998; Bret-Harte and others 2004). We constructed resin bags by placing $8 \mathrm{~g}$ of ion-exchange resin (IONAC ${ }^{\circledR}$ NM-60 $\mathrm{H}^{+} / \mathrm{OH}^{-}$ Form, type 1 beads 16-50 mesh; J.T. Baker, Philipsburg, NJ, USA) in polypropylene mesh litterbags $(5 \mathrm{~cm} \times 5 \mathrm{~cm})$ with a $100-\mu \mathrm{m}$ mesh size. In May 2005, we placed five resin bags on top of the Sphagnum layer in all four sites. In May 2006 we retrieved the resin bags; two resin bags (one in 
Table 2. Environmental Conditions in the Four Study Sites

\begin{tabular}{|c|c|c|c|c|}
\hline & N-Sweden & C-Sweden & S-Sweden & Germany \\
\hline $\mathrm{N}$ deposition $\left(\mathrm{g} \mathrm{m}^{-2}\right)$ & 0.3 & 0.6 & 1.1 & 1.5 \\
\hline \multicolumn{5}{|c|}{ Exchangeable nutrients $\left(\mu \mathrm{g} \mathrm{g}^{-1}\right)$} \\
\hline $\mathrm{NH}_{4}^{+}$ & $10 \pm 2 \mathrm{a}$ & $19 \pm 6 \mathrm{ab}$ & $20 \pm 2 \mathrm{ab}$ & $28 \pm 6 b$ \\
\hline $\mathrm{NO}_{3}^{-}$ & $31 \pm 2 a$ & $38 \pm 5 a$ & $150 \pm 38 b$ & $126 \pm 31 b$ \\
\hline $\mathrm{N}$ total & $41 \pm 4 \mathrm{a}$ & $58 \pm 10 \mathrm{a}$ & $170 \pm 39 \mathrm{~b}$ & $154 \pm 36 b$ \\
\hline $\mathrm{PO}_{4}^{-}$ & $1 \pm 1$ & $4 \pm 2$ & $2 \pm 1$ & $6 \pm 1$ \\
\hline \multicolumn{5}{|l|}{ Water table depth $(\mathrm{cm})$} \\
\hline Containers & $15 \pm 1 \mathrm{a}$ & $13 \pm 1 \mathrm{a}$ & $13 \pm 1 \mathrm{a}$ & $24 \pm 1 \mathrm{~b}$ \\
\hline Control plots & $13 \pm 1 \mathrm{~b}$ & $12 \pm 1 \mathrm{~b}$ & $8 \pm 1 \mathrm{a}$ & $21 \pm 1 \mathrm{c}$ \\
\hline
\end{tabular}

See Figure 1. Nitrogen deposition values are averages in the $50 \mathrm{~km} \times 50 \mathrm{~km}$ grid cells from the EMEP model for the period 1994-2004 (Tarrasón and others 2006): accumulation of nutrients between May 2005 and May 2006 on ion-exchange resins placed on the moss surface ( $n=4-5)$; average water table depth (cm below moss surface) over eight measurements in May and August in containers and in control plots $(n=5)$. Values are means \pm SE. Different letters indicate significant differences between sites.

$\mathrm{N}-\mathrm{Sw}$ and one in $\mathrm{N}-\mathrm{Ge})$ were found to be ruptured and so were excluded from the analysis. The remaining resin bags were extracted overnight in $50 \mathrm{ml} 2 \mathrm{M} \mathrm{NaCl}$ in $0.1 \mathrm{M} \mathrm{HCl}$. The extracts were brought to neutral $\mathrm{pH}$ by the addition of $\mathrm{NaOH}$ and analyzed spectrophotometrically for $\mathrm{NH}_{4}{ }^{+}, \mathrm{NO}_{3}{ }^{-}$, and $\mathrm{PO}_{4}{ }^{-}$using an auto-analyzer (Skalar).

Water table depth was measured in one perforated PVC pipe in each mesocosm and control plot during each visit in May and August from 2003 to 2006. Because the sites were so far apart, each time it took about 2 weeks to visit them all. As the weather conditions varied during this period and between sites, our measurements give only a rough indication of the water table depth in each site.

Vascular plant species composition and abundance in the mesocosms and control plots were measured during the experiment using the pointquadrat method (Jonasson 1988) with a 150-point frame $(25 \mathrm{~cm} \times 37.5 \mathrm{~cm})$. At every point, a needle was lowered to the moss surface and all contacts with the vegetation were noted, specifying species for each hit. Abundance was measured in August 2003, 2004, 2005, and 2006. For data analysis, we used the change in cover between August 2003 and 2006. The total aboveground vegetation within the point-quadrat frame was harvested after the last point-quadrat recordings. All vascular plants were clipped flush with the moss surface and sorted into species. Dry weight was determined for all species after oven-drying for $48 \mathrm{~h}$ at $70^{\circ} \mathrm{C}$. For each species, the number of hits in the point-quadrats was strongly correlated to the aboveground vascular plant biomass at the final harvest $(P<0.001 ; 0.68$ $\left.<R^{2}<0.95 ; 13<n<70\right)$. For further analyses, we grouped the species into two plant types: ericoids, mainly A. polifolia, C. vulgaris, E. nigrum, E. tetralix and $V$. oxycoccus; and graminoids, mainly E. vaginatum, E. angustifolium, and R. alba.
Changes in Sphagnum species cover were measured using the abovementioned point-quadrat method between August 2003 and August 2006. Generally, the mesocosm or plot surface consisted completely of Sphagnum mosses. In each mesocosm and control plot, four plastic rods with bristles were placed to measure height increment. This method was derived from the cranked wire method (Clymo 1970; Limpens and others 2004). Sphagnum height increment was measured in May and August of the years 2003-2006. At the end of the experiment, a core (diameter $6.6 \mathrm{~cm}$ ) was cut around each of the four rods and separated into a capitulum section $(0-1 \mathrm{~cm})$ and a subcapitulum section $(1-3 \mathrm{~cm})$. The sections were stored in ziplock bags and kept cool during transport to the Netherlands. In the lab, all samples were sorted into Sphagnum species, after which dry weight was determined by oven-drying for $48 \mathrm{~h}$ at $70^{\circ} \mathrm{C}$. Because the species composition of the cores within a mesocosm and between mesocosms varied, we did not calculate biomass production per species. Average biomass production in summer was calculated by multiplying subcapitulum bulk density by average height increment between May and August 2004, 2005, and 2006. For data analyses of height increment, we used cumulative height increment measured between May 2004 and August 2006.

When sorting the species from N-Sw in the lab, we found specimens of both $S$. balticum and Sphagnum angustifolium (Russ.) C. Jens. These species are difficult to distinguish, as Russow (Smith 1978) and Klinggraff (Daniels and Eddy 1985) found: they identified both species as varieties of $S$. recurvum. In our samples, we were unable to quantify the exact percentages of $S$. balticum and S. angustifolium. When reporting the results, therefore, whenever we mention S. balticum from $\mathrm{N}-\mathrm{Sw}$, we are referring to a mixture of $S$. balticum 
and S. angustifolium. We grouped the Sphagnum species into two moss types: hollow Sphagna, that is, S. balticum, S. cuspidatum (in control plots S-Sw) and S. fallax (in control plots N-Ge), and hummock Sphagna, that is, S. fuscum and S. magellanicum (in control plots S-Sw and N-Ge).

For nutrient analyses, we used the aboveground green vascular plant parts and Sphagnum capitula harvested in each mesocosm. Total $\mathrm{N}$ and phosphorus (P) concentrations were determined for ericoids, graminoids, hollow, and hummock Sphagnum species, by digesting $300 \mathrm{mg}$ of homogenous, milled material with sulphuric acid, salicylic acid, selenium, and hydrogen peroxide. All samples were analyzed spectrophotometrically for total $\mathrm{N}$ and $\mathrm{P}$ using an auto-analyzer (Skalar).

\section{Data Analyses}

Differences among the transplantation sites in nutrient deposition, water table depth in the containers, and vascular plant aboveground biomass, Sphagnum production, plant nutrient concentrations, and water table depth in control plots, were tested with one-way analysis of variance (ANOVA). To test for the effects of southward transplantation on species abundances, vascular plant aboveground biomass, Sphagnum production and nutrient concentrations, initially three-way ANOVAs were used with transplantation site (C-Sw, S-Sw, N-Ge), site of origin (N-Sw, C-Sw) and plant or moss type (ericoids versus graminoids or hollow Sphagnum versus hummock Sphagnum) as independent factors. As for most variables, there was a significant interaction of transplantation site by plant type, we also conducted two-way ANOVA's for each species group with transplantation site and site of origin as independent factors. In these analyses, the N-Sw transplantation site was left out of the ANOVAs because only mesocosms from origin $\mathrm{N}-\mathrm{Sw}$ had been (back)transplanted to site $\mathrm{N}-\mathrm{Sw}$. The N-Sw transplantation site is included in figures and posthoc analyses per site of origin, but could not be used in a balanced analysis including both sites of origin.

We used a Tukey post-hoc test to analyze the differences among the three or four transplantation sites. When a Levene test indicated that variances were not homogeneous, we used the Dunnett C test, which is similar to Tukey but does not assume equal variances, to test for differences among the sites. Aboveground biomass data were ln-transformed prior to analyses for better homogeneity of variances. To test for the effects of cutting the mesocosms and putting them in containers, we compared control mesocosms, that is, mesocosms in container back-transplanted to their site of origin, to control plots (not in container) in three-way ANOVAs of two container treatments by two sites of origin by two plant/moss types. When there were significant interactions with container treatment, subsequent two-way or one-way ANOVA's were used. All analyses were conducted using the SPSS statistical package for Windows (15.0).

\section{RESUltS}

\section{Environmental Conditions}

The north-south transect showed an increase in annual mean temperature from 3.9 to $9.6^{\circ} \mathrm{C}$ (Table 1). In every year and every season, the $\mathrm{N}-\mathrm{Ge}$ site had the highest temperature. The difference in temperature between the S-Sw and C-Sw site was rather small, with summer temperatures being even slightly lower in S-Sw than in C-Sw. Annual precipitation was around $500 \mathrm{~mm}$ for three of the four sites, but was much higher in the S-Sw site (Table 1). Calculated potential evapotranspiration increased from north to south (data not shown), resulting in decreasing effective precipitation from north to south, except for S-Sw which showed relatively high values as a result of the high precipitation (Table 1). The summers of 2003 and 2006 were warm, with long dry spells. As Table 2 shows, the water table depth in the mesocosms was similar in the Swedish sites but was deeper in the German site during our visits in May and August. Measured water table depth in the control plots was most shallow in S-Sw and deepest in N-Ge.

Table 2 shows the average $\mathrm{N}$ deposition per site from the EMEP model (Tarrasón and others 2006) and availability of $\mathrm{NH}_{4}{ }^{+}, \mathrm{NO}_{3}{ }^{-}$, and $\mathrm{PO}_{4}{ }^{-}$at the moss surface as measured by accumulation on ionexchange resins. Both $\mathrm{N}$ deposition and $\mathrm{N}$ availability $\left(\mathrm{NH}_{4}{ }^{+}\right.$and $\left.\mathrm{NO}_{3}{ }^{-}\right)$increased from north to south along the transect. The availability of $\mathrm{NH}_{4}{ }^{+}$ showed a gradual increase along the gradient, whereas the availability of $\mathrm{NO}_{3}{ }^{-}$increased more sharply: it was four times higher in the southern sites S-Sw and N-Ge than in the two northern sites (Table 2). There were no significant differences in $\mathrm{PO}_{4}{ }^{-}$availability among the sites $(F=2.07$, $P=0.15)$, although $\mathrm{PO}_{4}{ }^{-}$was relatively low in sites $\mathrm{N}-\mathrm{Sw}$ and S-Sw.

\section{Changes in Vegetation Composition}

Southward transplantation of the bog mesocosms resulted in significant changes in plant species 
abundances as measured in permanent quadrats in each mesocosm (Figure 2). The transplantation effect depended on plant or moss type, as there were significant transplantation site by plant/moss type interactions $(P=0.003$ and $P=0.022$ in three-way ANOVA of three sites by two origins by two plant/ moss types, for vascular plants and Sphagnum, respectively). Ericaceous dwarf shrubs increased strongly in abundance when transplanted to the $\mathrm{N}$-Ge site (Figure 2, Table 3). This was mainly due to an increase in $V$. oxycoccus and C. vulgaris (data not shown). Graminoids from $\mathrm{N}-\mathrm{Sw}$ expanded strongly during the experiment, but did so at all transplantation sites (Figure 2, Table 3). There was a tendency of largest graminoid expansion at the $\mathrm{C}$-Sw site (Figure 2). In the control plots, graminoids also increased in abundance but to a lesser degree than in the control mesocosms in containers $(P=0.034$ in two-way ANOVA of two container treatments by two origins).

The strong expansion of ericoids during the experiment when transplanted to the most south-

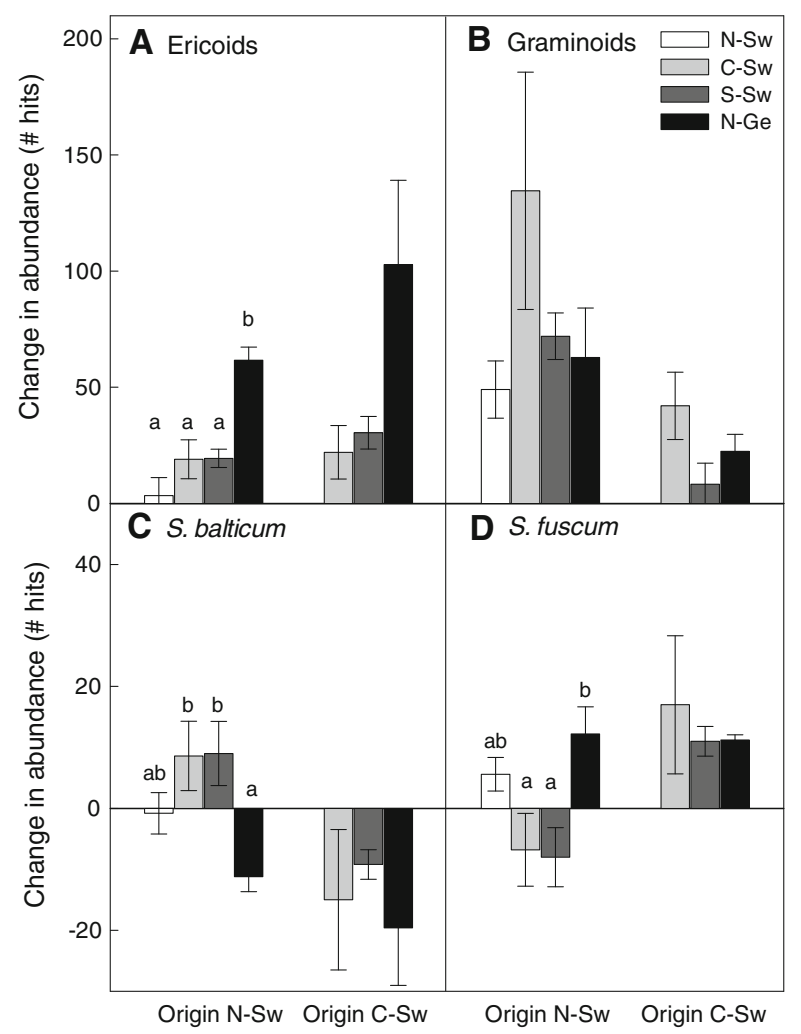

Figure 2. Change in abundance (number of hits) between August 2003 and August 2006 for vascular plants: (A) ericoids and (B) graminoids and for Sphagnum (C) S. balticum, and (D) S. fuscum. Different letters indicate significant differences between transplantation sites for each site of origin and plant/moss type. Data are mean values $\pm \mathrm{SE}, n=5$. ern site corresponded with the largest aboveground biomass of ericoids at the end of the experiment at the N-Ge site (Figure 3, Table 3). For the graminoids, aboveground biomass was largest at the C-Sw site. As a result, total aboveground vascular plant biomass in the transplanted mesocosms was largest at the N-Ge and C-Sw sites. When looking at the undisturbed control plots in the north-south transect, similar response patterns arise with largest aboveground vascular plant biomass in $\mathrm{N}-\mathrm{Ge}$, dominated by ericoids, and C-Sw, dominated by graminoids (Figure 3). Ericoid aboveground biomass was smallest at the S-Sw site.

Sphagnum species composition also changed in response to transplantation southward, but to a lesser extent than vascular plant abundance. Hollow Sphagnum, mainly S. balticum, from N-Sw decreased in cover at the N-Ge site (Figure 2). Hollow Sphagnum from C-Sw decreased at all transplantation sites. The decreases in hollow Sphagnum were accompanied by increases in hummock Sphagnum cover, as the total moss cover did not change.

\section{Sphagnum Growth}

From May 2003 to August 2006, Sphagnum grew on average $32 \mathrm{~mm}$ in height. In the first growing season of the experiment, both dominant species of the two northern sites, S. balticum and S. fuscum showed the smallest height increment in the most southern site (Figure 4). However, from May 2004 there were opposing site effects in these two species, demonstrated by a significant species by site interaction $(P=0.005$ in three-way ANOVA of 3 sites by two origins by two Sphagnum species). $S$. balticum showed a decreasing trend when transplanted southward, whereas S. fuscum had the largest height increment at the most southern site and the lowest height increment in S-Sw (Figure 4, Table 3).

As a result of the opposing trends in height increment in the two dominant species, Sphagnum production in the mesocosms did not differ significantly among the transplantation sites (Figure 5, Table 3). However, as we analyzed the mesoscosms that were transplanted to C-Sw, S-Sw, and N-Ge, we did observe a different response in Sphagnum production between mesocosms from the two sites of origin (Table 3). Going southward, Sphagnum production seemed to increase in mesocosms from $\mathrm{N}-\mathrm{Sw}$, whereas production seemed to decrease in mesocosms from C-Sw. We did not differentiate Sphagnum production by species because many of the cores collected around the cranked wires for determination of subcapitulum bulk density con- 
Table 3. Results of Two-way ANOVAs ( 3 Transplantation Sites $\times 2$ Origins) for Change in Abundance over the Period August 2003 to August 2006, for Aboveground Vascular Plant Biomass, for Sphagnum Height Increment Between May 2004 and August 2006, and for Plant Tissue Concentrations of N, P, and N:P Ratio for Ericoids, Graminoids, S. balticum, and S. fuscum

\begin{tabular}{|c|c|c|c|c|c|}
\hline \multirow[t]{2}{*}{ Variable } & \multirow[t]{2}{*}{ Plant/moss type } & \multicolumn{3}{|c|}{ ANOVA ( 3 Sites $\times 2$ Origins) } & \multirow[t]{2}{*}{ Posthoc site } \\
\hline & & Site & Origin & Site $\times$ Origin & \\
\hline \multirow[t]{5}{*}{ Change in abundance } & Ericoids & 0.001 & 0.183 & 0.483 & $\mathrm{C}-\mathrm{Sw}, \mathrm{S}-\mathrm{Sw}<\mathrm{N}-\mathrm{Ge}$ \\
\hline & Graminoids & 0.102 & 0.003 & 0.565 & \\
\hline & Total vascular plants & 0.064 & 0.093 & 0.381 & \\
\hline & S. balticum & 0.089 & 0.007 & 0.553 & \\
\hline & S. fuscum & 0.243 & 0.009 & 0.110 & \\
\hline \multirow[t]{3}{*}{ Aboveground biomass } & Ericoids & 0.001 & 0.893 & 0.819 & $\mathrm{~S}-\mathrm{Sw}, \mathrm{C}-\mathrm{Sw}<\mathrm{N}-\mathrm{Ge}$ \\
\hline & Graminoids & 0.002 & 0.073 & 0.809 & $\mathrm{~S}-\mathrm{Sw}<\mathrm{C}-\mathrm{Sw}$ \\
\hline & Total vascular plants & 0.001 & 0.264 & 0.814 & $\mathrm{~S}-\mathrm{Sw}<\mathrm{C}-\mathrm{Sw}, \mathrm{N}-\mathrm{Ge}$ \\
\hline \multirow[t]{2}{*}{ Height increment 2004-2006 } & S. balticum & 0.008 & 0.523 & 0.049 & $\mathrm{~N}-\mathrm{Ge}, \mathrm{S}-\mathrm{Sw}<\mathrm{C}-\mathrm{Sw}$ \\
\hline & S. fuscum & 0.030 & 0.529 & 0.915 & $\mathrm{~S}-\mathrm{SW}<\mathrm{N}-\mathrm{Ge}$ \\
\hline Production & Sphagnum & 0.881 & 0.203 & 0.035 & \\
\hline \multirow[t]{4}{*}{$\mathrm{N}$} & Ericoids & 0.089 & 0.002 & 0.033 & \\
\hline & Graminoids & 0.003 & 0.107 & 0.519 & $\mathrm{C}-\mathrm{Sw}<\mathrm{S}-\mathrm{Sw}$ \\
\hline & S. balticum & $<0.001$ & 0.016 & 0.269 & $\mathrm{C}-\mathrm{Sw}<\mathrm{S}-\mathrm{Sw}, \mathrm{N}-\mathrm{Ge}$ \\
\hline & S. fuscum & 0.003 & 0.583 & 0.302 & $\mathrm{C}-\mathrm{Sw}<\mathrm{N}-\mathrm{Ge}$ \\
\hline \multirow[t]{4}{*}{$\mathrm{P}$} & Ericoids & 0.239 & 0.966 & 0.068 & \\
\hline & Graminoids & 0.063 & 0.848 & 0.852 & \\
\hline & S. balticum & $<\mathbf{0 . 0 0 1}$ & 0.495 & 0.483 & $\mathrm{~S}-\mathrm{Sw}<\mathrm{C}-\mathrm{Sw}<\mathrm{N}-\mathrm{Ge}$ \\
\hline & S. fuscum & $<0.001$ & 0.988 & 0.354 & $\mathrm{~S}-\mathrm{Sw}<\mathrm{C}-\mathrm{Sw}, \mathrm{N}-\mathrm{Ge}$ \\
\hline \multirow[t]{4}{*}{$\mathrm{N}: \mathrm{P}$} & Ericoids & 0.023 & 0.259 & 0.050 & $\mathrm{C}-\mathrm{Sw}, \mathrm{N}-\mathrm{Ge}<\mathrm{S}-\mathrm{Sw}$ \\
\hline & Graminoids & 0.124 & 0.019 & 0.753 & \\
\hline & S. balticum & $<0.001$ & 0.007 & 0.002 & $\mathrm{C}-\mathrm{Sw}, \mathrm{N}-\mathrm{Ge}<\mathrm{S}-\mathrm{Sw}$ \\
\hline & S. fuscum & $<\mathbf{0 . 0 0 1}$ & 0.431 & 0.010 & $\mathrm{C}-\mathrm{Sw}, \mathrm{N}-\mathrm{Ge}<\mathrm{S}-\mathrm{Sw}$ \\
\hline
\end{tabular}

Aboveground biomass data were In-transformed prior to analysis. Note that the N-Sw transplantation site could not be included in these analyses. Bold entries indicate significant effects $(P<0.05)$.

tained mixtures of Sphagnum species. There were no container effects on Sphagnum production $(P=0.37$ in two-way ANOVA of two control treatments by two origins). In the control plots, there was a significant site effect, with the largest Sphagnum production at the $\mathrm{S}-\mathrm{Sw}$ site and the smallest production at the N-Ge site (Figure 5).

\section{Nutrient Concentrations}

There were very strong site effects on nutrient concentrations, both in Sphagnum and in vascular plants (Table 3). In Sphagnum, N concentrations increased southward, from 5.3 and $6.5 \mathrm{mg} \mathrm{g}^{-1}$ in $\mathrm{N}-\mathrm{Sw}$, to 10.0 and $10.1 \mathrm{mg} \mathrm{g}^{-1}$ in $\mathrm{N}-\mathrm{Ge}$, for $S$. balticum and $S$. fuscum, respectively (Figure 6). Phosphorus concentrations were largest in the $\mathrm{C}-\mathrm{Sw}$ and N-Ge site (Figure 6). The patterns in $\mathrm{N}$ and P concentrations in Sphagnum correspond with the patterns of $\mathrm{N}$ and $\mathrm{P}$ availabilities as measured by ion-exchange resins placed at the moss surface (Table 2). In mesocosms and control plots in the $\mathrm{S}-\mathrm{Sw}$ site, the N:P ratios were very large, that is,
25-34, compared to 15-19 in the other sites (data not shown). For vascular plants, $\mathrm{N}$ concentrations were largest at the two southern sites, particularly in the graminoids (Figure 7).

$P$ concentrations were remarkably invariable around $0.6 \mathrm{mg} \mathrm{g}^{-1}$, except for lower concentrations in ericoids in control plots in site S-Sw (data not shown). $\mathrm{N}: \mathrm{P}$ ratios were smaller in ericoids than in graminoids, 15 and 19 on average, respectively, and were smaller at the N-Ge and C-Sw site (Figure 7), the sites with the largest aboveground biomass of vascular plants.

\section{Discussion}

\section{Experimental Set-Up}

In this study, we transplanted bog mesocosms with intact vegetation to more southern bog sites to study the response of northern bog ecosystems to increasing temperature and $\mathrm{N}$ deposition. Although a reciprocal experimental design, that is, transplantations from four sites of origin to the same 


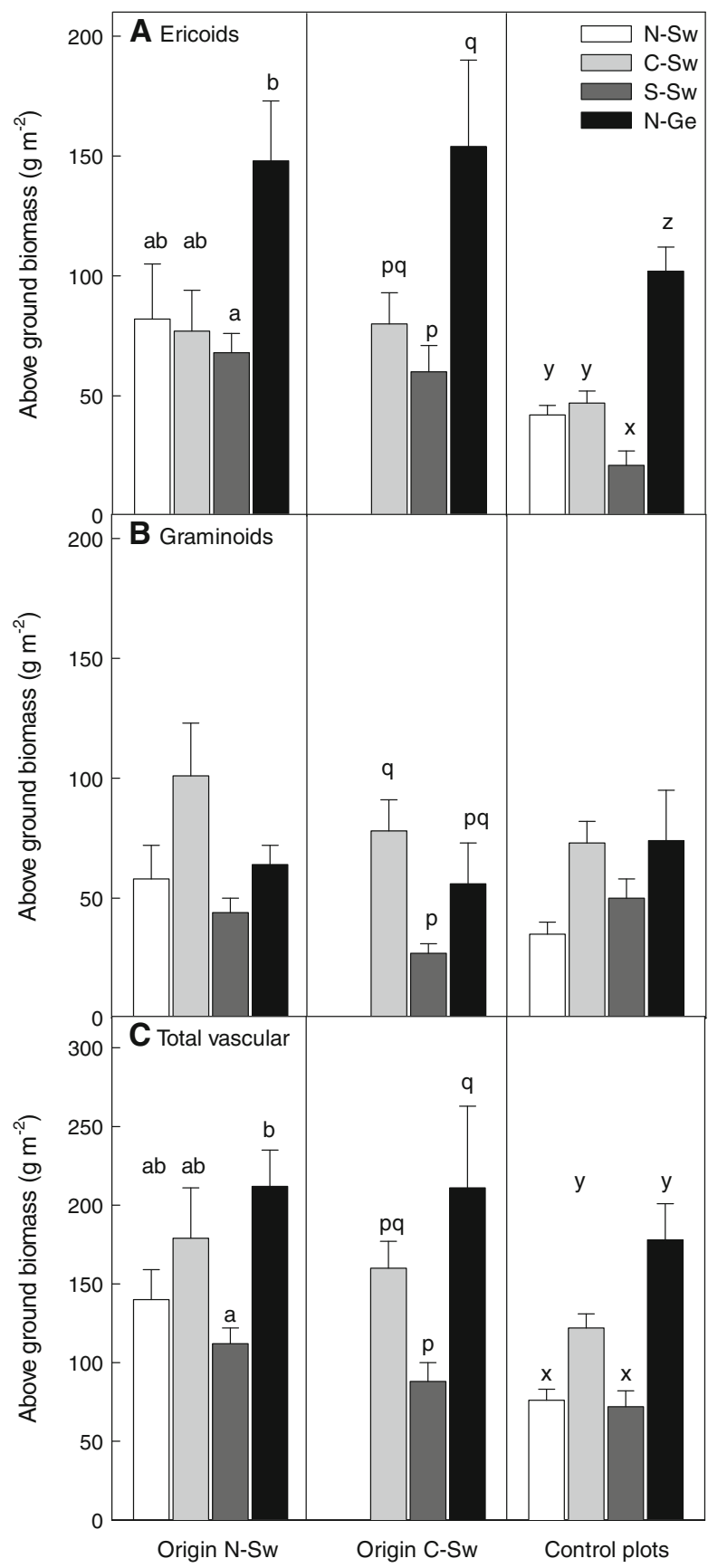

Figure 3. Aboveground vascular plant biomass for (A) ericoid and $(\mathbf{B})$ graminoid species, and for $(\mathbf{C})$ the total of vascular plants. Different letters indicate significant differences between transplantation sites and between control plots $(P<0.05)$. Data are means \pm SE, $n=5$.

four transplantation sites, would have allowed for a stronger statistical data analysis of the effects of (increasing or decreasing) temperature $/ \mathrm{N}$ deposition, it would not have given more information on the response to warmer conditions.

For transplantation, it was necessary to cut the mesocosms, lift them out and put them in con- tainers that were perforated on the sides close to the bottom, to allow exchange of water. By comparison of control mesocosms with control plots (without container) we found container effects on vascular plants, but not on mosses (Table 4). The disturbance of digging out the mesocosms may have stimulated vascular plant expansion due to an initial increase in nutrient availability from decomposing dead roots. Although the container treatment has contributed to the general increase in vascular plant abundance during the transplantation experiment, a comparison with observations over the natural gradient (that is, in the control plots) shows that the container effect did not strongly affect the outcome of the transplantation experiment. The response of aboveground vascular plant biomass to southward transplantation was in agreement with differences in ericoid and graminoid aboveground biomass among the four sites along the natural gradient; even though there were differences in ericoid and graminoid species composition among the control plots of the four sites (see site description). Wiedermann and others (2009) also found analogous outcomes in a field experiment and a gradient study, which suggests that small-scale field experiments, when run for a sufficiently long time, can predict the direction and magnitude of ecosystem responses to changing environmental conditions.

The latitudinal gradient of our study included both a temperature gradient and an $\mathrm{N}$ deposition gradient. Within Europe it is impossible to find a north-south gradient in the boreal to temperate region which is not also an $\mathrm{N}$ deposition gradient (Limpens and others 2006). Therefore, from this study we cannot disentangle temperature from $\mathrm{N}$ deposition effects. Sphagnum N concentration and N accumulation on ion-exchange resins placed at the moss surface confirmed that there was a north to south increase in atmospheric $\mathrm{N}$ input, with a clear distinction between the two northern sites and the two southern sites. Annual temperature during our experiment indeed increased from north to south (3.9, 7.0, 7.4, and $9.6^{\circ} \mathrm{C}$ ), but the $\mathrm{S}-\mathrm{Sw}$ site appeared climatologically a bit of an outlier with a more oceanic climate (more precipitation, relatively cool summer) than the other three sites. The gradient in temperature also has consequences for plant water availability. Higher temperatures generally cause the evapotranspiration rate to increase, which would mean a reduction in effective precipitation (precipitation minus evapotranspiration) when there is no accompanying increase in precipitation. It can therefore be expected that moss water availability is lower in the N-Ge site than in 


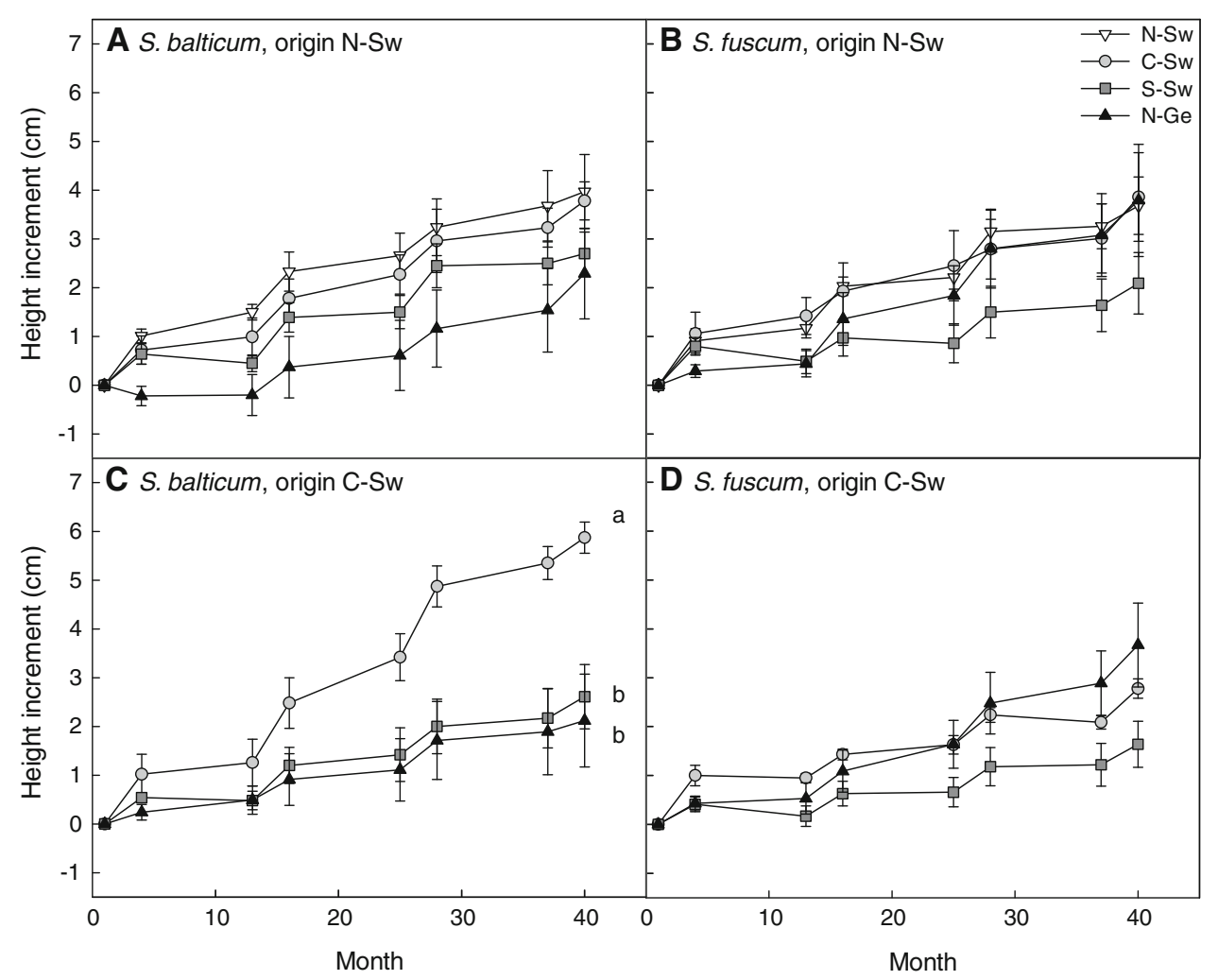

Figure 4. Cumulative height increment for (A) S. balticum and (B) $S$. fuscum from N-Sw and (C) S. balticum and (D) $S$. fuscum from C-Sw between May 2003 and August 2006. Different letters indicate significant differences between transplantation sites for each site of origin and species. Data are means $\pm \mathrm{SE}, n=5$.

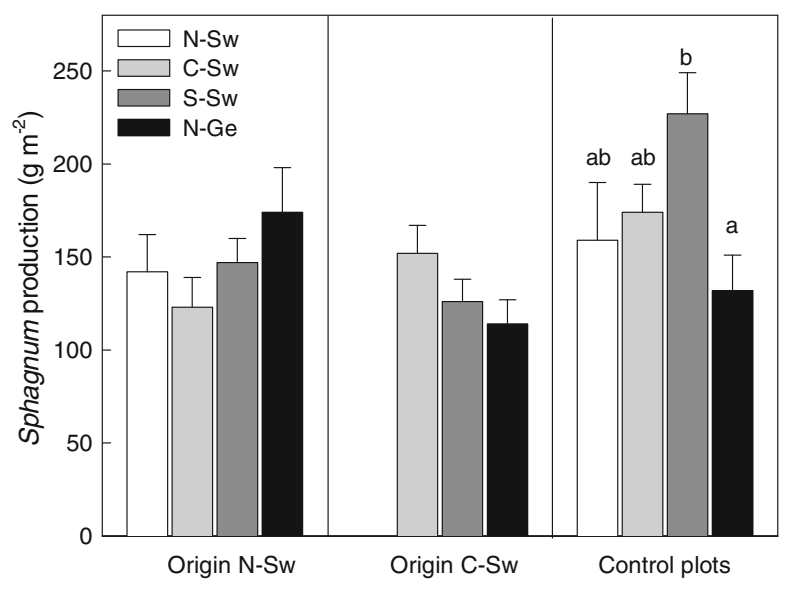

Figure 5. Average Sphagnum biomass production between May and September, calculated from height increment in summer 2004, 2005, and 2006. Dominant Sphagnum species in the control plots differed between the sites; in N-Sw and C-Sw the species S. fuscum and S. balticum were most abundant, in the control plots in S-Sw dominant species were $S$. magellanicum and $S$. cuspidatum and in control plots in N-Ge dominant species were $S$. magellanicum and $S$. fallax. Different letters indicate significant differences between transplantation sites and between control plots $(P<0.05)$. Data are means \pm SE, $n=5$.

the three northern sites. Our limited set of water table measurements confirms that effective precipitation has been lower at the most southern site.

\section{Response of Vascular Plants}

As expected, the southward transplantation of bog mesocosms increased vascular plant cover. This was mainly attributed to the ericaceous dwarf shrubs. Not only $\mathrm{N}$ deposition increased southward, but also temperatures increased, which may have enhanced nutrient mineralization (Chapin and others 1995; Breeuwer and others 2008b), but also resulted in reduced effective precipitation in the most southern site. In a field experiment in northern Sweden in which temperature and $\mathrm{N}$ supply have been manipulated in a factorial design, both factors increased vascular plant cover and reduced Sphagnum cover, but the effect of temperature was weaker (Wiedermann and others 2007). In our experiment, the drier conditions in the most southern site due to reduced effective precipitation likely contributed to the observed strong expansion of ericoids. Dwarf shrub aboveground biomass was smallest at the wettest site, despite relatively high $\mathrm{N}$ deposition, pointing to the sensitivity of dwarf shrub cover to hydrological conditions. Dwarf shrubs are well known to benefit from drier conditions in bogs (Weltzin and others 2003). Also when the water table is lower only in summer due to increased evapotranspiration or summer drought, vascular plant cover may shift from graminoids to ericoids (Breeuwer and others 2009b). 

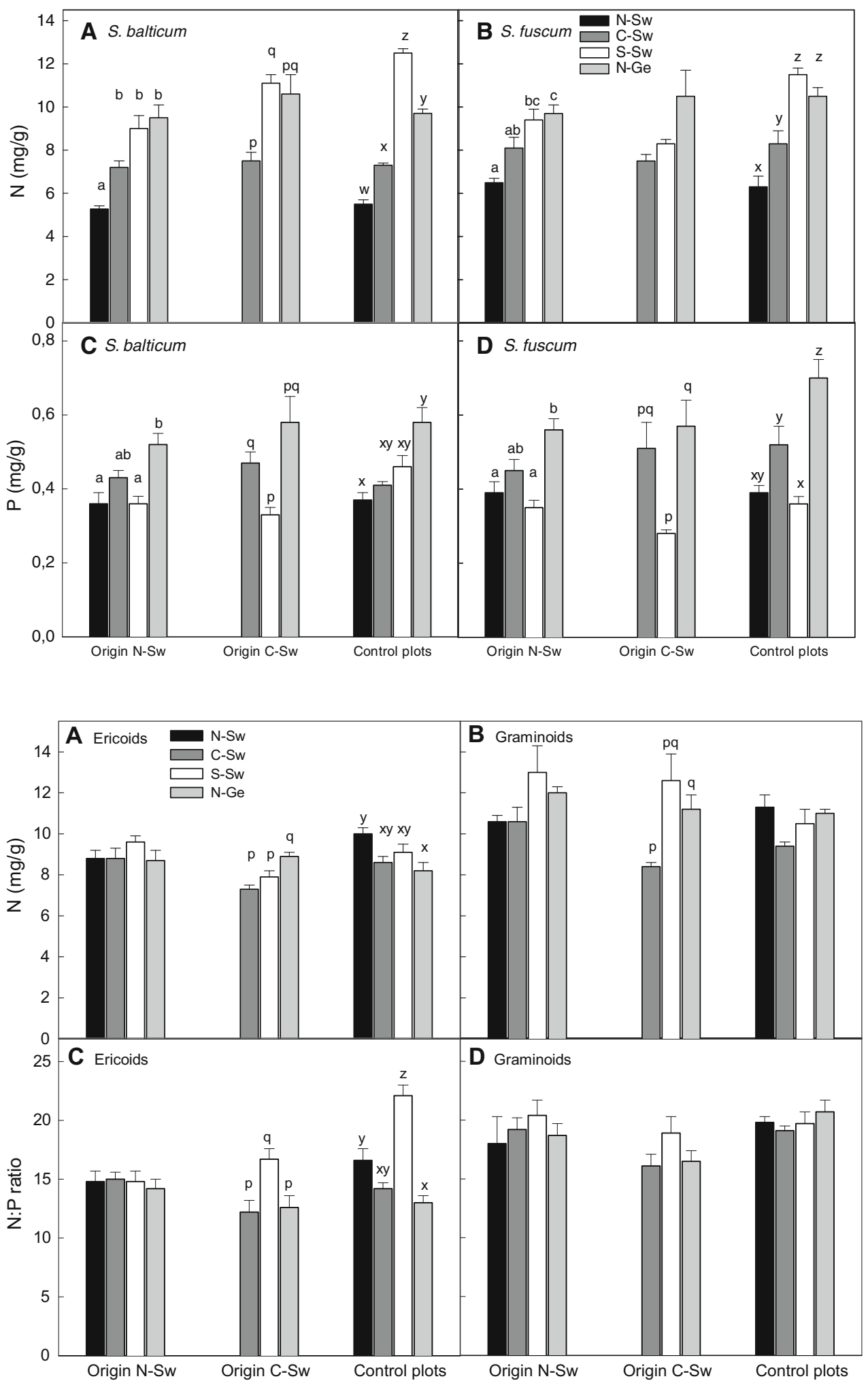

Figure 6. Nitrogen and $\mathrm{P}$ concentrations of $(\mathbf{A}, \mathbf{C})$ S. balticum (S. cuspidatum in control plots in S-Sw and $S$. fallax in control plots in N-Ge) and (B, D) S. fuscum (S. magellanicum in control plots in S-Sw and N-Ge). Different letters indicate significant differences between transplantation sites and between control plots for each moss type $(P<0.05)$. Data are means $\pm \mathrm{SE}, n=5$.
Figure 7. Nitrogen concentrations of $(\mathbf{A})$ ericoids, (B) graminoids and $\mathrm{N}: \mathrm{P}$ ratio of $(\mathbf{C})$ ericoids, and (D) graminoids. Different letters indicate significant differences between transplantation sites and between control plots for each plant type $(P<0.05)$. Data are means $\pm \mathrm{SE}, n=5$.
We expected that graminoids would also profit from being transplanted to more nutrient-rich conditions resulting from warming-induced stimulation of soil nutrient mineralization and high $\mathrm{N}$ deposition. Competition theory predicts that at increasing nutrient supply the graminoids with larger potential growth rates and larger leaf area ratios should gain a competitive advantage over dwarf shrubs (Berendse 1994). It could be that even in the most southern site with high $\mathrm{N}$ deposition, 
Table 4. Results of Three-way ANOVAs ( 2 Container Treatments $\times 2$ Origins $\times 2$ Plant/moss Types) to Test for the Effects of Container Treatment (Mesocosms in Container Back-Transplanted to Their Site of Origin versus Control Plots without Container)

\begin{tabular}{lrrrrrrr}
\hline & Container & \multicolumn{1}{c}{ Origin } & \multicolumn{1}{c}{ Type } & Co $\times$ Or & Co $\times$ Ty & Or $\times$ Ty & Co $\times$ Or $\times$ Ty \\
\hline Vascular plants & & & & & & & \\
$\quad$ Change in abundance & $\mathbf{0 . 0 2 6}$ & 0.309 & $\mathbf{0 . 0 0 5}$ & 0.829 & 0.117 & 0.796 & 0.133 \\
Aboveground biomass & $\mathbf{0 . 0 0 5}$ & $\mathbf{0 . 0 1 2}$ & 0.828 & 0.409 & 0.256 & 0.078 & 0.470 \\
N concentration & $<\mathbf{0 . 0 0 1}$ & $<\mathbf{0 . 0 0 1}$ & $<\mathbf{0 . 0 0 1}$ & 0.663 & 0.500 & 0.193 & 0.848 \\
P concentration & 0.346 & 0.430 & 0.072 & 0.734 & 0.780 & 0.120 & 0.531 \\
N:P ratio & $\mathbf{0 . 0 0 8}$ & $\mathbf{0 . 0 1 7}$ & $<\mathbf{0 . 0 0 1}$ & 0.635 & 0.717 & 0.442 & 0.748 \\
Mosses & & & & & & & \\
Change in abundance & 0.851 & 0.925 & $\mathbf{0 . 0 0 1}$ & 0.866 & 0.910 & 0.955 & $\mathbf{0 . 0 2 4}$ \\
Height increment 2004-2006 & 0.062 & $\mathbf{0 . 0 0 2}$ & 0.066 & 0.114 & 0.166 & $\mathbf{0 . 0 1 0}$ & 0.500 \\
N concentration & 0.536 & $<\mathbf{0 . 0 0 1}$ & $\mathbf{0 . 0 0 3}$ & 0.644 & 0.577 & 0.305 & 0.193 \\
P concentration & 0.742 & $\mathbf{0 . 0 0 1}$ & 0.063 & 0.583 & 0.547 & 0.255 & 0.486 \\
N:P ratio & 0.496 & 0.359 & 0.694 & 0.263 & 0.485 & $\mathbf{0 . 0 1 9}$ & 0.854 \\
& & & & & & & \\
Bold entries indicate significant effects $(P<0.05)$. & & & & & & & \\
\hline
\end{tabular}

nutrients were still limiting vascular plant growth, as it is well known that peat mosses are very effective accumulators of nutrients. A dense Sphagnum carpet thus prevents vascular plants from having direct access to nutrients deposited in the moss layer (Malmer and others 2003). Even in a high $\mathrm{N}$ deposition site, less than $10 \%$ of atmospheric $\mathrm{N}$ supply was directly available to vascular plants (Heijmans and others 2002b). Within the vascular plants, the ericoids have easier access to the atmospheric $\mathrm{N}$ than the graminoids, because the ericoids have more superficial roots (Heijmans and others 2002b; Rydin and Jeglum 2006). In other experiments in bogs, shallow-rooting species like $V$. oxycoccus responded more to $\mathrm{N}$ addition than did graminoid species (Lütke Twenhöven 1992; Heijmans and others 200 lb; Wiedermann and others 2007). Apart from having better access to atmospheric nutrients, ericoids could also be better competitors than graminoids in peatlands (Ward and others 2009). In a competition experiment where the species had equal access to the supplied nutrients, two dwarf shrub species were better competitors than two cooccurring graminoid species at increasing $\mathrm{N}$ and $\mathrm{P}$ supply (Kool and Heijmans 2009).

Phosphorus also seems to play an important role. It was remarkable that there was very little variation in $\mathrm{P}$ concentration in the vascular plants, suggesting that any additional available $\mathrm{P}$ has been used for growth. In addition, aboveground vascular plant biomass was largest in the two sites with the highest $\mathrm{P}$ availability as indicated by accumulation of $\mathrm{P}$ on ion-exchange resins, $\mathrm{P}$ concentrations in moss tissues, and low N:P ratios in vascular plants. Because the N:P ratios of graminoids were not only higher than those of the ericoids, but also all exceeded 16, the value defined by Koerselman and Meuleman (1996) as indicating P limitation, it seems that graminoid growth has been more limited by P availability than growth of ericoids. From our results, we cannot provide conclusive evidence for which mechanism(s) caused ericoids to benefit from southward transplantation, whereas graminoids did not respond.

\section{Response of Sphagnum}

We could not demonstrate that transplanting the mesocosms southward had a negative effect on production of Sphagnum. Southward transplantation did increase the photosynthetic capacity for both dominant Sphagnum species, which was mainly explained by increasing tissue $\mathrm{N}$ concentrations (Granath and others 2009). However, Sphagnum biomass production was not (S. balticum) or only weakly (S. fuscum) correlated with maximum photosynthetic rate, indicating that factors other than photosynthetic capacity strongly determine Sphagnum productivity. In the natural gradient, Sphagnum production was largest in the S-Sw site, the site with the highest precipitation. The bog vegetation in the region in which this site is located seems to react differently from bog vegetation in other regions in northwest Europe. Gunnarsson and Flodin (2007) found an increase of species typical of wetter conditions in this site, whereas vegetation shifts toward drier conditions occured in other regions of northwest Europe. That Sphagnum production at the S-Sw site was larger in the control plots than in the mesocosms, can be due to the 
dominance of more productive Sphagnum species at that site (S. magellanicum/S. cuspidatum in control plots versus $S$. fuscum/S. balticum from northern sites in mesocosms), but also due to wetter site conditions in the control plots than in the mesocosms.

Although Sphagnum production did not respond to transplantation southward, the two dominant Sphagnum species did show differential responses. After the first year, $S$. balticum had the lowest height increment at the German site, whereas S. fuscum had the largest height increment at that site. This resulted in a reduction of $S$. balticum cover at the most southern site. It is likely that the drier conditions of the German site, which are related to the higher temperatures, contributed to this decline in cover of this hollow/lawn species and the increase in the hummock species. Robroek and others (2007) also found that height increment and production of $S$. fuscum were not affected by a decrease in water table, whereas those of the lawn species $S$. magellanicum were. During the summer heat wave in Europe in 2003, Sphagnum production rates in an alpine ombrotrophic bog were 30\% lower than in other years in S. fuscum dominated hummocks and 50\% lower than average in lawn communities, which showed signs of desiccation even though summer precipitation was not lower than average (Gerdol and others 2007). This implies that $S$. fuscum can increase its competitive power under drier conditions.

$S$. balticum also seems sensitive to high $\mathrm{N}$ deposition. Height increment was also low at the wet $\mathrm{S}$-Sw site. This site has relatively high $\mathrm{N}$ deposition, which resulted in very high $\mathrm{N}: \mathrm{P}$ ratios in moss tissues. In other field experiments $S$. balticum responded negatively to $\mathrm{N}$ addition (Gunnarsson and others 2004; Wiedermann and others 2009). S. fuscum has been shown to respond positively to $\mathrm{N}$ addition at low $\mathrm{N}$ deposition rates in Canadian peatlands (Vitt and others 2003). For the two dominant Sphagnum species of our transplantation experiment, we did an additional greenhouse experiment in which temperature and $\mathrm{N}$ supply were varied in factorial design (Breeuwer and others 2009a). We found that both factors reduced height increments in both S. balticum and S. fuscum, but it was mainly temperature that depressed the cover of the hollow species. In a competition experiment with four temperature treatments, $S$. balticum lost competitive advantage over S. fuscum at the highest temperature treatment of $20.6^{\circ} \mathrm{C}$ (Breeuwer and others $2008 \mathrm{a}$ ), which is only $2.5^{\circ} \mathrm{C}$ warmer than summer temperatures in the German site. In both greenhouse experiments, water tables were maintained at a high level and there were no signs of desiccation of capitula, so that observed temperature effects were unlikely to be related to insufficient water availability. Moreover, the shift in competitive relationships with increasing temperature is in agreement with the more northern distribution of $S$. balticum compared to S. fuscum.

\section{Implications for the Future of Ombrotrophic Bogs}

Although in our transplantation experiment, using a latitudinal gradient in which both temperature and $\mathrm{N}$ deposition increased, we could not disentangle temperature from $\mathrm{N}$ deposition effects, from other studies it becomes clear that both factors work in the same direction. In a 10-year field experiment in northern Sweden, both increased temperatures and increased $\mathrm{N}$ supply drastically increased vascular plant cover, up to $70 \%$ cover, at the cost of total Sphagnum cover, but only after at least 4 years of experimental treatments (Wiedermann and others 2007, 2009). Within 4 years, the Sphagnum species composition did change, with reductions in S. balticum growth and cover in response to temperature and $\mathrm{N}$ treatments (Gunnarsson and others 2004).

The strong expansion of dwarf shrubs we observed at the German site resulted in an aboveground vascular plant biomass of $240 \mathrm{~g} \mathrm{~m}^{-2}$ four growing seasons after transplantation. This value is not very high and corresponds to a light interception of approximately 40\% (Breeuwer and others 2009b), suggesting that vascular plant cover was probably not dense enough to seriously affect Sphagnum growth (Heijmans and others 2002a). In an alpine bog site, vascular plants did expand at the expense of Sphagnum mosses, probably triggered by the exceptional heat wave in 2003 (Gerdol and others 2008).

Although in this 3-year study, we could not demonstrate that vascular plant expansion was at the cost of Sphagnum growth, our results on dwarf shrub expansion and increased $\mathrm{N}$ concentrations in plant tissues do point in the direction of a positive feedback in the long term. If high $\mathrm{N}$ availability through deposition and enhanced nutrient mineralization continues, the addition of Sphagnum litter with high $\mathrm{N}$ concentrations to the peat will lead to $\mathrm{N}$-enriched peat, which will stimulate N-mineralization and expansion of vascular plant cover even more. Thus, the competitive balance between vascular plants and Sphagnum can be expected to shift to the benefit of vascular plants, which over time will increase the proportion of vascular plant litter in peat. As vascular plant litter is much more decomposable than Sphagnum litter (Hobbie 1996; 
Dorrepaal and others 2005; Bragazza and others 2007) and its decomposition is accelerated more by an increase in temperature (Breeuwer and others 2008b), the litter turnover will accelerate and nutrients will become more readily available -again benefiting the vascular plants more than the Sphagnum. If the total cover of ericoids and graminoids were to increase strongly, shading from the vascular plants could adversely affect Sphagnum growth (Hayward and Clymo 1983; Heijmans and others 2001b). Model runs for 100 years with our bog ecosystem model suggest that particularly the combination of high temperature and high $\mathrm{N}$ deposition causes a shift from Sphagnum-dominated to vascular plant dominated bog vegetation, which reduces long-term carbon accumulation rates (Heijmans and others 2008).

Concluding, the dwarf shrub expansion and increased $\mathrm{N}$ concentrations in plant tissues we observed, point in the direction of a positive feedback toward vascular plant-dominance suppressing peat-forming Sphagnum in the long term. However, our data also indicate that precipitation and $\mathrm{P}$ availability influence the competitive balance among Sphagnum, dwarf shrubs, and graminoids.

\section{ACKNOWLEDGMENTS}

We thank Mats Nilsson, Håkan Rydin, Bo Wallén, Nils Malmer, and Beate Blahy for suggesting study sites. We thank Bas van Geel, Marjolein van der Linden, Maurits Gleichman, Marleen Pierik, Ineke Breeuwer and Gertjan Spierings for their assistance in the field and Jan van Walsem, Frans Möller and Anne-Marie van den Driessche for lab work on the samples. Joy Burrough advised on the English. This study was financed by the Netherlands Organization for Scientific Research (NWO-project 110015-01).

\section{OPEN ACCESS}

This article is distributed under the terms of the Creative Commons Attribution Noncommercial License which permits any noncommercial use, distribution, and reproduction in any medium, provided the original author(s) and source are credited.

\section{REFERENCES}

Backeus II. 1985. Aboveground production and growth dynamics of vascular bog plants in central Sweden. Acta Phytogr Suecica 74:1-98.

Berendse F. 1994. Competition between plant populations at low and high nutrient supplies. Oikos 71:253-60.
Berendse F, Breemen Nv, Rydin H, Buttler A, Heijmans MMPD, Hoosbeek MR, Lee JA, Mitchell E, Saarinen T, Vasander H, Wallen B. 2001. Raised atmospheric $\mathrm{CO}_{2}$ levels and increased $\mathrm{N}$ deposition cause shifts in plant species composition and production in Sphagnum bogs. Global Change Biol 7:591-8.

Bouwman A, Van Vuuren D, Derwent R, Posch M. 2002. A global analysis of acidification and eutrophication of terrestrial ecosystems. Water Air Soil Pollut 141:349-82.

Bragazza L. 2008. A climatic threshold triggers the die-off of peat mosses during an extreme heat wave. Global Change Biol $14: 2688-95$.

Bragazza L, Freeman C, Jones T, Rydin H, Limpens J, Fenner N, Ellis T, Gerdol R, Hajek M, Lacumin P, Kutnar L, Tahvanainen T, Toberman H. 2006. Atmospheric nitrogen deposition promotes carbon loss from peat bogs. Proc Natl Acad Sci USA 103:19386-9.

Bragazza L, Siffi C, Iacumin P, Gerdol R. 2007. Mass loss and nutrient release during litter decay in peatland: the role of microbial adaptability to litter chemistry. Soil Biol Biochem 39:257-67.

Breeuwer A, Heijmans MMPD, Gleichman M, Robroek BJM, Berendse F. 2009a. Response of Sphagnum species mixtures to increased temperature and nitrogen availability. Plant Ecol 204:97-111.

Breeuwer A, Heijmans MMPD, Robroek BJM, Berendse F. 2008a. The effect of temperature on growth and competition between Sphagnum species. Oecologia 156:155-67.

Breeuwer A, Heijmans MMPD, Robroek BJM, Limpens J, Berendse F. 2008b. The effect of increased temperature and nitrogen deposition on decomposition in bogs. Oikos 117:1258-68.

Breeuwer A, Robroek BJM, Limpens J, Heijmans MMPD, Schouten MGC, Berendse F. 2009b. Decreased summer water table depth affects peatland vegetation. Basic Appl Ecol 10:330-9.

Bret-Harte MS, Garci EA, Sacre VM, Whorley JR, Wagner JL, Lipper SC, Chapin FSIII. 2004. Plant and soil responses to neighbour removal and fertilization in Alaskan tussock tundra. J Ecol 92:635-47.

Bubier JL, Moore TR, Bledzki LA. 2007. Effects of nutrient addition on vegetation and carbon cycling in an ombrotrophic bog. Global Change Biol 13:1168-86.

Chapin FSIII, Shaver GR, Giblin AE, Nadelhoffer KJ, Laundre JA. 1995. Responses of arctic tundra to experimental and observed changes in climate. Ecology 76:694-711.

Clymo RS. 1970. The growth of Sphagnum: methods of measurement. J Ecol 58:13-49.

Clymo RS, Hayward PM. 1982. The ecology of Sphagnum. In: Smith AJE, Ed. Bryophyte ecology. London: Chapman and Hall. p 229-89.

Coulson JC, Butterfield J. 1978. An investigation of the biotic factors determining the rates of plant decomposition on blanket bog. J Ecol 66:631-50.

Daniels RE, Eddy A. 1985. Handbook of European Sphagna. London: HMSO.

Dorrepaal E, Aerts R, Cornelissen JHC, Logtestijn RSPv, Callaghan TV. 2006. Sphagnum modifies climate-change impacts on subarctic vascular bog plants. Funct Ecol 20:31-41.

Dorrepaal E, Cornelissen JHC, Aerts R, Wallen B, Logtestijn RSPv. 2005. Are growth forms consistent predictors of leaf litter quality and decomposability across peatlands along a latitudinal gradient? J Ecol 93:817-28. 
Gerdol R, Bragazza L, Brancaleoni L. 2008. Heatwave 2003: high summer temperature, rather than experimental fertilization, affects vegetation and $\mathrm{CO}_{2}$ exchange in an alpine bog. New Phytol 179:142-54.

Gerdol R, Petraglia A, Bragazza L, Iacumin P, Brancaleoni L. 2007. Nitrogen deposition interacts with climate in affecting production and decomposition rates in Sphagnum mosses. Global Change Biol 13:1810-21.

Granath G, Strengbom J, Breeuwer A, Heijmans MMPD, Berendse F, Rydin H. 2009. Photosynthetic performance in Sphagnum transplanted along a latitudinal nitrogen deposition. Oecologia 159:705-15.

Gunnarsson U. 2005. Global patterns of Sphagnum productivity. J Bryol 27:269-79.

Gunnarsson U, Flodin L-Å. 2007. Vegetation shifts towards wetter site conditions on oceanic ombrotrophic bogs in southwestern Sweden. J Veget Sci 18:595-604.

Gunnarsson U, Granberg G, Nilsson M. 2004. Growth, production and interspecific competition in Sphagnum: effects of temperature, nitrogen and sulphur treatments on a boreal mire. New Phytol 163:349-59.

Gunnarsson U, Rydin H. 2000. Nitrogen fertilization reduces Sphagnum production in bog communities. New Phytol 147:527-37.

Hayward PM, Clymo RS. 1983. The growth of Sphagnum: experiments on, and simulation of, some effects of light flux and water-table depth. J Ecol 71:845-63.

Heijmans MMPD, Arp WJ, Berendse F. 2001 a. Effects of elevated $\mathrm{CO}_{2}$ and vascular plants on evapotranspiration in bog vegetation. Global Change Biol 7:817-27.

Heijmans MMPD, Berendse F, Arp WJ, Masselink AK, Klees H, Visser Wd, Breemen Nv. 2001b. Effects of elevated carbon dioxide and increased nitrogen deposition on bog vegetation in the Netherlands. J Ecol 89:268-79.

Heijmans MMPD, Klees H, Berendse F. 2002a. Competition between Sphagnum magellanicum and Eriophorum angustifolium as affected by raised $\mathrm{CO}_{2}$ and increased $\mathrm{N}$ deposition. Oikos 97:415-25.

Heijmans MMPD, Klees H, Visser Wd, Berendse F. 2002b. Effects of increased nitrogen deposition on the distibution of 15 N-labeled nitrogen between Sphagnum and vascular plants. Ecosystems 5:500-8.

Heijmans MMPD, Mauquoy D, Van Geel B, Berendse F. 2008. Long-term effects of climate change on vegetation and carbon dynamics in peat bogs. J Veget Sci 19:307-20.

Hobbie SE. 1996. Temperature and plant species control over litter decomposition in Alaskan tundra. Ecol Monogr 66:50322.

Hobbie SE, Chapin FSIII. 1998. The response of tundra plant biomass, aboveground production, nitrogen and $\mathrm{CO}_{2}$ flux to experimental warming. Ecology 79:1526-44.

Jonasson S. 1988. Evaluation of the point intercept method for the estimation of plant biomass. Oikos 52:101-6.

Kivinen E, Pakarinen P. 1980. Peatland areas and the proportion of virgin peatlands in different countries. In: 6th International Peat Congress, Duluth. pp 52-4

Koerselman W, Meuleman AFM. 1996. The vegetation N:P ratio: a new tool to detect the nature of nutrient limitation. J Appl Ecol 33:1441-50.

Kool A, Heijmans MMPD. 2009. Dwarf shrubs are stronger competitors than graminoid species at high nutrient supply in peat bogs. Plant Ecol 204:125-34.
Limpens J, Berendse F. 2003. How litter quality affects mass loss and N loss from decomposing Sphagnum. Oikos 103:537-47.

Limpens J, Berendse F, Klees H. 2004. How phosphorus availability affects the impact of nitrogen deposition on Sphagnum and vascular plants in bogs. Ecosystems 7:793-804.

Limpens J, Heijmans MMPD, Berendse F. 2006. The nitrogen cycle in boreal peatlands. In: Wieder RK, Vitt DH, Eds. Boreal peatland ecosystems. Berlin, Heidelberg: Springer-Verlag. $p$ 195-230.

Lütke Twenhöven F. 1992. Competition between two Sphagnum species under different deposition levels. J Bryol 17:71-80.

Malmer N, Albinsson C, Svensson BM, Wallen B. 2003. Interferences between Sphagnum and vascular plants: effects on plant community structure and peat formation. Oikos 100:469-82.

Malmer N, Svensson BM, Wallen B. 1994. Interactions between Sphagnum mosses and field layer vascular plants in the development of peat-forming systems. Folia Geobot Phytotaxonom 29:483-96.

Robroek BJM, Limpens J, Breeuwer A, Schouten MGC. 2007. Effects of water level and temperature on performance of four Sphagnum mosses. Plant Ecol 190:97-107.

Rustad LE, Campbell JL, Marion GM, Norby RJ, Mitchell MJ, Hartley AE, Cornelissen JHC, Gurevitch J. 2001. A metaanalysis of the response of soil respiration, net nitrogen mineralization, and aboveground plant growth to experimental ecosystem warming. Oecologia 126:543-62.

Rydin H, Jeglum J. 2006. The biology of peatlands. Oxford: Oxford University Press.

Smith AJE. 1978. The moss flora of Britain and Ireland. Cambridge: Cambridge University Press.

Solomon S, Qin D, Manning M, Chen Z, Marquis M, Averyt KB, Tignor M, Miller HL. 2007. IPCC, 2007: Climate change 2007: The physical science basis. Contribution of Working Group I to the fourth assessment report of the Intergovernmental Panel on Climate Change. Cambridge University Press, Cambridge.

Tarrasón L, Fagerli H, Klein H, Simpson D, Benedictow AC, Vestreng V. 2006. Trends of air-concentrations and depositions since 1990 to 2004. EMEP Status Report 1/2006, EMEP.

Turunen J, Roulet NT, Moore TR, Richard PJH. 2004. Nitrogen deposition and increased carbon accumulation in ombrotrophic peatlands in eastern Canada. Global Biogeochem Cycle 18(GB3002):1-12.

Van Breemen N. 1995. How Sphagnum bogs down other plants. Trends Ecol Evol 10:270-5.

Vitt DH, Wieder K, Halsey LA, Turetsky M. 2003. Response of Sphagnum fuscum to nitrogen deposition: a case study of ombrogenous peatlands in Alberta, Canada. The Bryologist 106:235-45.

Ward SE, Bardgett RD, McNamara NP, Ostle NJ. 2009. Plant functional group identity influences short-term peatland ecosystem carbon flux: evidence from a plant removal experiment. Funct Ecol 23:454-62.

Weltzin JF, Bridgham SD, Pastor J, Chen J, Harth C. 2003. Potential effects of warming and drying on peatland plant community composition. Global Change Biol 9:141-51.

Wiedermann MM, Gunnarsson U, Nilsson MB, Nordin A, Ericson L. 2009. Can small-scale experiments predict ecosystem responses? An example from peatlands. Oikos 118:449.

Wiedermann MM, Nordin A, Gunnarsson U, Nilsson MB, Ericson L. 2007. Global change shifts vegetation and plant-parasite interactions in a boreal mire. Ecology 88:454-64. 